\title{
Behavioral antecedents of accidental injuries in early childhood: a study of twins
}

\author{
Adam P Matheny Jr, Anne M Brown, Ronald S Wilson
}

Accidents are the leading cause of death among preschool children; they account for as many fatalities as congenital malformations, pneumonia, cancer, and meningitis combined. Serious accidents also cause many permanent disabilities among children, and less serious accidents are so pervasive as to be considered an inevitable condition of childhood. It has been demonstrated, however, that some individuals are much more prone to accidents than others. Some studies have considered environmental hazards, socioeconomic level, inadequacy of supervision, stress within the family, etc, as predisposing a child to accidental injuries. ${ }^{14}$ Other investigators have looked at the injured children themselves in a search for characteristics associated with an accident habit. ${ }^{23}$ There is substantial agreement on how accident-prone children typically behave but disagreement as to why. Such children are described as unusually active, aggressive, reckless, temperamental, impulsive, and easily distracted. A weakness of these studies has been that the child's behavioral characteristics have been assessed subsequent to their having had accidents-the possibility being that the accident caused the observed behavior rather than vice versa. Identifying behaviors prior to the accidents is necessary in order to validate the hypothesis of accident proneness.

Pairs of twins provide an ideal situation for isolating behaviors characteristic of accidentprone children. The children in a pair share the same parents, social class, and environmental hazards, and a greater number of accidents in one twin than in the co-twin should be related more to behavioral differences than to environmental differences. This study was undertaken to see if, in fact, children who differed behaviorally in early life would subsequently have different accident histories. Because of the characteristics consistently attributed to accident-prone children, it was hypothesized that the relatively more active, temperamental, and less attentive infant would subsequently have more accidents.

\section{Methods and results}

SUBJECTS

Forty nine pairs of same-sex twins (26 male, 23 female) were selected (from a larger sample of twins participating in a longitudinal study) on the basis of having been recruited as infants into the study; and at least one member of the pair having had at least one accident prior to his sixth birthday.

\section{BEHAVIORAL RELATIONS}

The data on the within-pair behavioral differ? ences were taken from observations by the twins $s$ mothers who are interviewed periodically in the longitudinal study. At every visit the mother was queried about each twin's health (including accidents) and about readily identifiable behaviors related to temperament, sociability, and aspects of cognitive development. She was askedo to specify similarities (concordance) or differ $\vec{\imath}$ ences (discordance) between the twins' behaviors. When differences were noted, theinterviewer recorded which twin (twin A or twine B) was perceived as displaying the behavior more prominently. In this way, relatively subtlen individual differences could be outlined. Each behavior was categorized in one of 3 ways: twin A displayed it more, twin $\mathrm{B}$ displayed it more, or both twins displayed it equally.

Since the interest in this study was on behavioral characteristics of the twins prior to their having accidents, the interview at one yeat? was selected to provide the within-pair behas vioral comparisons. The 3 variables selected from the interview data at one year weres temper frequency, attention span during play ${ }_{\bar{\sigma}}$ and amount of spontaneous, general activity in? a wide variety of situations.

\section{ACCIDENT DATA}

Interviews subsequent to the one-year visit provided the data on accidents, and only those accidents serious enough to receive medicatos attention were analyzed. Automobile accidents were included only if the child was a pedestrian. These data are presented in table 1 byo age of sex of child and type of accident.

Head injuries, which accounted for better than half of accidents, included concussions, ? fractures, lacerations, and broken teeth. Intox- 0 ication included ingestion of such substances as?

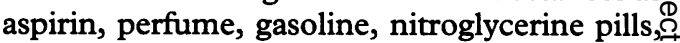
and dexedrine. They category 'Other' consisted $\mathbb{Q}$ of such accidents as being struck by a car, near-? suffocation, and drowning. The number of accidents for boys ( 64 per cent) was a little less్ than twice as high as the number for girls-the expected differential for non-lethal as well as? lethal accidents. ${ }^{1}$ As age increased there was a decline in the total number of accidents; this also is consistent with other studies on nonautomotive accidents. 
Table 1 Distribution of accidents by type of injury, age, and sex of twin

\begin{tabular}{|c|c|c|c|c|c|c|c|c|c|c|c|c|c|}
\hline \multirow[b]{2}{*}{ Age (years) } & \multicolumn{2}{|c|}{ Head } & \multicolumn{2}{|c|}{$\begin{array}{l}\text { Fractures other } \\
\text { than head }\end{array}$} & \multicolumn{2}{|c|}{$\begin{array}{l}\text { Burns other } \\
\text { than head }\end{array}$} & \multicolumn{2}{|c|}{ Intoxication } & \multicolumn{2}{|c|}{$\begin{array}{l}\text { Lacerations other } \\
\text { than head }\end{array}$} & \multicolumn{2}{|c|}{ Other } & \multirow[b]{2}{*}{ Total } \\
\hline & $M$ & $F$ & $M$ & $F$ & $M$ & $F$ & $M$ & $F$ & $M$ & $F$ & $M$ & $F$ & \\
\hline $\begin{array}{l}1-2 \\
2-3 \\
3-4 \\
4-5 \\
5-6\end{array}$ & $\begin{array}{l}7 \\
9 \\
9 \\
6 \\
3\end{array}$ & $\begin{array}{r}5 \\
10 \\
2 \\
1 \\
1\end{array}$ & $\begin{array}{l}0 \\
3 \\
2 \\
2 \\
0\end{array}$ & $\begin{array}{l}1 \\
0 \\
1 \\
0 \\
0\end{array}$ & $\begin{array}{l}1 \\
0 \\
3 \\
1 \\
1\end{array}$ & $\begin{array}{l}0 \\
3 \\
0 \\
0 \\
0\end{array}$ & $\begin{array}{l}1 \\
2 \\
0 \\
1 \\
0\end{array}$ & $\begin{array}{l}2 \\
2 \\
1 \\
0 \\
0\end{array}$ & $\begin{array}{l}1 \\
4 \\
3 \\
1 \\
0\end{array}$ & $\begin{array}{l}0 \\
0 \\
1 \\
1 \\
0\end{array}$ & $\begin{array}{l}1 \\
1 \\
0 \\
0 \\
0\end{array}$ & $\begin{array}{l}0 \\
1 \\
0 \\
0 \\
1\end{array}$ & $\begin{array}{l}19 \\
35 \\
22 \\
13 \\
6\end{array}$ \\
\hline Total & 34 & 19 & 7 & 2 & 6 & 3 & 4 & 5 & 9 & 2 & 2 & 2 & 95 \\
\hline
\end{tabular}

\section{RELATION BETWEEN ACCIDENTS AND} BEHAVIOR

In order to relate the behavioral variables at one year and the accidents at subsequent years, each twin pair was categorized as to whether twin A (or B) had more accidents or whether the twins had the same number of accidents. Of the 49 pairs of twins, there was only one pair in which the twins had an equal number of accidents.

Each of the 3 behavioral variables, as well as the accident variable, was paired with every other variable and $2 \times 2 \chi^{2}$ tests were performed to see whether twins maintained the same relationship on both variables. That is, if twin A (or B) was reported as being more active, was he also reported as having more accidents? Or conversely, if one twin was reported as having a longer attention span, was he reported as having fewer accidents? In the latter case, the relation between the behaviors would be inverse. Twin pairs concordant on each of the variables were excluded from the $\chi^{2}$ analyses because of sample size and the low frequency of concordance.

The $\chi^{2}$ values indicate that the twins with more accidents had been more active $(p<0.01)$, temperamental $(p<0.01)$, and less attentive $(p<0.05)$ than their co-twins when reported on at one year of age. On the behavioral variables, the amount of general activity was most strongly related to accident frequency. Among the 43 twin pairs discordant on activity and accident frequency, the more active infant twin accounted for 71 out of 89 accidents reported for those pairs. To indicate the nature of the accidents reported the histories of two pairs of twins are illustrative.

\section{Case reports}

CASE 1

In a male pair, twin $B$ was the more active, temperamental, and inattentive twin at one year of age. During subsequent visits, he was reported to have suffered a head injury (4 stitches taken) at 33 months, burned his foot on a vaporizer at 47 months, broken his collar bone at $\mathbf{4 8}$ months, and broken his collarbone again at 56 months. His less active twin had suffered no serious accidents at the time of study.

\section{CASE 2}

In a female pair, twin $A$ was reported as being more active, temperamental but less attentive at 12 months. Prior to her sixth birthday, she had a head concussion from a fall down the basement steps, had her stomach pumped because of aspirin ingestion, and had broken a finger. Twin $B$ had suffered no accidents during this period.

\section{Comment}

The results from this study add support to the hypothesis that some children are prone to have more accidents than others. Although environmental hazards, quality caretaking, and other factors cannot be ignored for their roles in the production of accidents, the concept of the accident-prone child appears to be a viable one.

1 Meyer RJ, Roelofs HA, Redmond S. Accidental injury to the preschool child. F Pediatr 1963; 63: 95.

Krall V. Personality characteristics of accident repeating children. $\mathcal{F}$ Soc Psychol 1953; 99.

3 Manheimer DI, Mellinger G. Personality characteristics of the child accident repeater. Child Dev 1967; 38: 491.

4 Haddon W, Suchman EA, Klein D. Accident research methods and approaches. New York: Harper and Row, 1964

\section{Novel approach to teen drinking and driving}

Police in Weymouth, MA, are now towing cars of teenagers who are drinking and partying in the woods, forcing the kids to find another way home and forcing them or their parents to pay $\$ 55$ to get the car back. 'That's a pretty expensive can of beer', notes Officer Gomes (Patriot Ledger, 30 April 1996).

\section{Louisiana upholds minimum drinking age}

The Louisiana Supreme Court upheld a state law setting the minimum drinking age at 21 years, thus preserving its eligibility for federal highway funds, in conformity with the National Minimum Drinking Age Act of 1988, New York Times, 3 July 1996). 